\title{
When Palestinians Became Human Shields: Counterinsurgency, Racialization, and the Great Revolt (1936-1939)
}

\section{CHARLES ANDERSON}

\author{
Department of History, Western Washington University, Bellingham, \\ WA, USA
}

On 24 September 1936, Palestinian rebel fighters conducted a multipronged assault on British targets in Nablus. The raid was testament to the growing boldness and reach of the rebels, whose power had waxed in late summer as their months-old insurgency deepened throughout the country. During what the military later purported was only a heavy barrage of sniping, the local commanding officer, Brigadier J. F. Evetts, took an extraordinary step as countermeasure. Fearing a decisive rebel offensive on the city's garrison, he summoned the mayor, Sulayman Tuqan, to army headquarters. Tuqan believed that he was being brought in for consultation with government officials, but when he arrived, he was escorted to the roof of the building, where he was forced to spend the night as a visible, high-value human shield. Outraged by the incident, Tuqan subsequently returned his Order of the British Empire commendation in protest and the entire Nablus municipal council threatened to resign. News of the unusual event spread quickly in Palestine while the Daily Telegraph in London referred to it as an episode of "Black and Tan" conduct, referencing the paramilitary police notorious for repression in Ireland. Palestine's High Commissioner, Arthur Grenfell Wauchope, objected to the military authorities' intentional endangerment of an "innocent," much less one of Tuqan's stature, but J. G. Dill, the General Officer Commanding (GOC), refused to foreswear the future use of human shields and instead endorsed the practice as an economical means of support and CSSH's anonymous peer reviewers for their valuable role in improving the article. 
defending British forces. Indeed, in his account of the episode the rebels broke off their attack on the army headquarters as soon as the mayor arrived on the spot. The end of the Palestinian revolt's first phase three weeks later in October temporarily curtailed the question of human shields. ${ }^{1}$

The Nablus incident is the first undisputed use of human shields, the practice of employing hostages on the battlefield, during the Great Revolt (1936-1939). ${ }^{2}$ Beginning as a general strike in April 1936 that rapidly gave rise to a popular insurgency, the revolt constituted the most dramatic Arab challenge to Britain's control of Palestine, which it had seized as a colony in World War I and ruled thereafter as a Mandate under the League of Nations. ${ }^{3}$ Although it has often been depicted as a disorganized failure, ${ }^{4}$ the rebel movement vexed the British for over three years and its partisans (Arab youth, workers, women, and peasants) demonstrated considerable resilience, ingenuity, and flexibility in their enduring struggle. During the second and more severe period of the revolt (1937-1939) lightly armed rebels beat back the colonial authorities from broad stretches of the country, establishing themselves as a state-in-formation and putting continued colonial control of the territory in serious jeopardy. As a growing body of scholarship shows, Britain only turned back the Palestinian insurgency after unleashing a harsh repertoire of collective

${ }^{1}$ High Commissioner (henceforth HC) to Colonial Undersecretary (Parkinson), 16 Oct. 1936, and associated correspondence, British National Archive (BNA), Colonial Office (CO) 733/316/11.

${ }^{2}$ For two other incidents of human shielding in 1936 recorded by Arabs, see Fawzi al-Qawuqji, Filastin fi mudhakkirat al-Qawuqji, vol. 2, prepared by Khayriyya Qasimiyya (Beirut: Munadhdhimat al-Tahrir al-Filastiniyya, Markaz al-Abhath and Dar al-Quds, 1975), 31-34; and 'Izzat Darwaza, Mudhakkirat Muhammad 'Izzat Darwaza, 1305 h-1404 h/1887 m-1984 m (Beirut: Dar al-Gharb al-Islami, 1993), vol. 2, 166-67.

3 While technically distinct from the prior colonial era, the Mandate system shared with it both the withholding of sovereignty from the colonized population and what Manu Goswami refers to as the "ideological structure of temporal deferral," postponing the moment of self-determination perpetually into the future. See Goswami, Producing India: From Colonial Economy to National Space (Chicago: University of Chicago Press, 2004), 245. On the League of Nations in the Middle East, see Michael Provence, The Last Ottoman Generation and the Making of the Modern Middle East (New York: Cambridge University Press, 2017).

${ }^{4}$ E.g., Tom Bowden, "The Politics of the Arab Rebellion in Palestine, 1936-39," Middle Eastern Studies 11, 2 (1975), 147-74; Yehoshua Porath, The Palestinian Arab National Movement: From Riots to Rebellion (London: Frank Cass, 1977); Yuval Arnon-Ohana, "The Bands in the Palestinian Arab Revolt, 1936-1939: Structure and Organization," Asian and African Studies 15 (1981): 229-47, 237-38; Matthew Hughes, Britain's Pacification of Palestine: The British Army, the Colonial State, and the Arab Revolt, 1936-1939 (Cambridge: Cambridge University Press, 2019); Steven Wagner, Statecraft by Stealth: Secret Intelligence and British Rule in Palestine (Ithaca: Cornell University Press, 2019). For strong critiques of this view, see Ted Swedenburg, Memories of Revolt: The 1936-1939 Rebellion and the Palestinian National Past (Fayetteville: University of Arkansas Press, 1995); Jacob Norris, "Repression and Rebellion: Britain's Response to the Arab Revolt in Palestine of 1936-39," Journal of Imperial and Commonwealth History 36, 1 (2008), 25-45; and Charles Anderson, "From Petition to Confrontation: The Palestinian National Movement and the Rise of Mass Politics, 1929-1939," PhD diss., New York University, 2013. 
punishments against the civilian population and by resorting to "dirty war" tactics like human shielding. ${ }^{5}$

Under the Hague Conventions of 1907, combatants were forbidden from forcing civilians into "operations ... against their own country." 6 After Germany's use of human shields during World War I in Belgium, the practice was tainted by its association with atrocities against civilians. ${ }^{7}$ In its most immediate context in Palestine, the use of human shields represented an effort to counterbalance the manifest weaknesses of the British campaign to suppress the revolt. As an artifact of the battlefield, human shields were meant to resolve an important tactical dilemma, namely the insurgents' consistent and effective targeting of transportation arteries for ambushes and attacks. Yet the practice of human shielding was not merely a battlefield exigency. It was also part of the little-known institutional struggle by the military to reject its subordinate role of supporting the colonial government in Palestine (as per the imperial military doctrine dubbed "Military Aid to the Civil Power," or MACP). ${ }^{8}$ The use of human shields, an unusual tactic associated with imperial badlands like India's Northwest Frontier Province,

5 Naomi Shepherd, Ploughing Sand: British Rule in Palestine 1917-1948 (New Brunswick: Rutgers University Press, 2000[1999]); Tom Segev, One Palestine, Complete: Jews and Arabs under the British Mandate, Haim Watzman, trans. (New York: Henry Holt Publishers, 2000); Norris, "Repression"; Matthew Hughes, "The Banality of Brutality: British Armed Forces and the Repression of the Arab Revolt in Palestine, 1936-39," English Historical Review 74, 507 (2009): 313-54; idem, "From Law and Order to Pacification: Britain's Suppression of the 193639 Arab Revolt in Palestine," Journal of Palestine Studies 39, 2 (2010): 6-22; idem, Britain's Pacification; Laleh Khalili, "The Location of Palestine in Global Counterinsurgencies," International Journal of Middle East Studies 42, 3 (2010): 413-33; idem, Time in the Shadows: Confinement in Counterinsurgencies (Stanford: Stanford University Press, 2013); Anderson, "From Petition," chs. 7-10; Matthew Kraig Kelly, The Crime of Nationalism: Britain, Palestine, and Nation-Building on the Fringe of Empire (Berkeley: University of California Press, 2017). An older tradition of scholarship largely ignored or excused the atrocities and copious violence of Britain's counterinsurgency (e.g., Bowden, "Politics").

${ }^{6}$ Quoted in Neve Gordon and Nicola Perugini, "The Politics of Human Shielding: On the Resignification of Space and the Constitution of Civilians as Shields in Liberal Wars," Environment and Planning D: Society and Space 34, 1 (2016), 168-87, 171.

7 Ibid., 171-72. See also Neve Gordon and Nicola Perugini, Human Shields: A History of People in the Line of Fire (Berkeley: University of California Press, 2020), ch. 4.

8 On MACP, see Robert Johnson, "Command of the Army, Charles Gwynn and Imperial Policing: The British Doctrinal Approach to Internal Security in Palestine 1919-29," Journal of Imperial and Commonwealth History 43, 4 (2015), 570-89, 570-78. Johnson's discussion on MACP in Palestine bears no resemblance to my argument here.

9 Khalili, Time, 20-21. The literature on human shielding has not focused on colonial Palestine. Perugini and Gordon have examined human shielding in Israel-Palestine since the second intifada (2000-2005), primarily in relation to discursive and legal claims made by Israel. Their work shows that Israeli allegations that Palestinians hide behind "human shields" in Gaza are designed to license Israel's willful assaults on civilian populations by purporting that they are inseparable from legitimate battlefield targets and therefore not protected under international law. See their "Politics of Human Shielding." Their book (cited above), which defines human shields very broadly (including so-called voluntary human shielding by peace, civil rights, and environmental activists), omits substantive coverage of Mandate Palestine. 
was only authorized by civilian authorities in Jerusalem and London after the fact. Its adoption in Palestine was part of a broader pattern of disregarding civilian authority and countermanding the tenets of MACP that fit the military's only semi-concealed quest to take direct control of the Mandate and assure its unfettered command over the effort to quell the Palestinian revolt. At the same time, the conversion of colonized bodies into literal shields bespoke a process of racialization that had profound effects for the Palestinians. Whereas the discursive and legal racialization of the Palestinians that stripped them of much of their political and juridical rights traced back to the Balfour declaration of 1917 (denying them rights as a political community) and the advent of collective punishment in the early years of British rule (effacing their individual legal rights), their corporeal racialization through practices like human shielding marked a new phase in the process - one intended to signal the utter disposability of Arab life. ${ }^{10}$

By delving into the practice of human shielding, this article makes several interventions. First, it spotlights the remarkable development and sweep of the Great Revolt during its second phase, which has been greatly underrated within the scholarly literature. ${ }^{11}$ The insurgency's upward arc in 1938 and the corresponding crisis of the colonial regime, as its hold on the country grew shakier and its counterinsurgent strategies proved unavailing, were critical to the emergence and regularization of human shielding. As this research reveals, human shields were a product of the British military's intensifying frustration as it fought to turn the tide against the surprisingly effective, dynamic, and adaptable rebel movement. Moreover, it discloses that the use of human shields was far more generalized and systematic than previously understood, becoming standard procedure on roads as well as railways. In turn, it traces how Palestinian rebels sought to surmount the callous and, in their view, barbaric and cowardly use of their fellow countrymen to protect British forces, the lifeblood of the occupying regime. Second, in tracking tensions between the civilian and military branches of the colonial state, it sheds new light on the militarization of the Mandate, and in particular on the

10 On the Balfour declaration, see Rashid Khalidi, The Iron Cage: The Story of the Palestinian Struggle for Statehood (Boston: Beacon, 2006), ch. 2. On collective punishment, see Ylana Miller, "Administrative Policy in Rural Palestine: The Impact of British Norms on Arab Community Life, 1920-1948," in Joel Migdal, ed., Palestinian Society and Politics (Princeton: Princeton University Press, 1980), 132; Shepherd, Ploughing Sand, 197-201; Anderson, "From Petition," 29-30, 87-88, 509-10, 521-24. On British racial discourses on Arabs and Palestine prior to Balfour, see Seraj Assi, "The Original Arabs: The Invention of the 'Bedouin Race' in Ottoman Palestine," International Journal of Middle East Studies 50, 2 (May 2018), 213-32.

11 Much of what's been written on the revolt fails to capture the seriousness of the threat it posed to the colonial government and concentrates instead on finding fault with it or itemizing the tactics by which it was crushed. Recent works like Hughes's Britain's Pacification, Wagner's Statecraft, and classic works like Porath's Palestinian Arab, all fit this mold. Swedenburg is one of the only scholars to stress the revolt's potency; see, for example, his Memories of Revolt. 
military's scheming for power and resistance to limits on its conduct, both civilian and doctrinal. The military's drive to repudiate civilian supremacy and its sense that MACP hampered the campaign against the Palestinians helped propel its adoption of brutish methods, including the regularization of human shields. Finally, while most accounts have sidestepped the aspect of racialization, and some have gone so far as to deny its salience altogether, this article contends to the contrary that the racialization of the Palestinians was integral to the campaign to defeat their independence movement in the 1930s and that this deepening trend constituted an important step in the broader dehumanization and marginalization of the Palestinians as a people.

\section{AND THE DEBATE OVER MILITARY CONTROL}

The first phase of the Palestinian revolt in 1936 did not end in a victory for British forces. ${ }^{12}$ Over the course of six months the size of the garrison grew some twelve-fold, reaching the strength of two divisions (twenty-five thousand men), and the military roundly defeated rebels in a host of battles. ${ }^{13}$ But the insurgency was as elusive as it was tenacious. Rebels often avoided head-on combat, melted away from engagements, and hid in plain sight amongst supportive Arab villagers. To dissuade the population from aiding or participating in the rebellion and because the colonial authorities had considerable trouble locating their quarry, they adopted a counterinsurgent strategy based on an expanding inventory of collective punishments. These tactics initially took the shape of financial penalties such as collective fines, home demolitions, and the confiscation and destruction of property, as well as curfews. Collective punishments were an accepted part of imperial doctrine and practice concerning population control, especially in the colonies. ${ }^{14}$ Part of the empire's illiberal traditions, the recourse to collective punishments contradicted core Western juridical principles including the presumption of innocence, the notion of individual rights, and the right to a trial. In their stead, the colonial authorities in Palestine operated according to a conception of collective guilt whereby broad segments of the population-towns, villages, urban quarters, whole citieswere held responsible in the event of hostilities in their vicinity. ${ }^{15}$ The wholesale adoption of collective sanctions constituted a critical step in an ongoing process of diminishing the political and moral, as well as legal, standing of the Palestinians in official eyes. By substituting the presumption

\footnotetext{
12 For a full narrative of 1936, see Anderson, "From Petition," ch. 7. See also Abdul-Wahhab Kayyali, Palestine: A Modern History (London: Croom Helm, 1978), ch. 7.

${ }_{13}$ Report by GOC (n.d.), part II (n.p.), enclosure to GOC to Undersecretary of War, 30 Oct. 1936, BNA, CO 733/317/1; Hughes, "Banality," 314.

14 Khalili, Time, esp. ch. 1; Johnson, "Command," 574, 576.

15 See note 10 .
} 
of guilt for that of innocence, the framework of collective punishment blurred the distinction between combatants and the general population, rendering the latter an open and defenseless target in lieu of the often-elusive rebels. ${ }^{16}$ Still, while he accepted and advocated for the use of collective punishments, High Commissioner Wauchope worried that if carried too far, the strategy threatened to permanently unwind British rule in Arab Palestine. He therefore sought to restrain the military from its most indiscriminate displays of force and, importantly, he largely acted to block the transfer of power from the civilian government to the military (via the declaration of martial law), which the Cabinet in London had authorized during the peak of the 1936 crisis. $^{17}$

The military was deeply angered and frustrated by events in Palestine and by what it viewed as undue constraints imposed on its operations. During the 1936 revolt its commanding officers, the Air Officer Commanding (AOC) R. E.C. Pierse and GOC Dill, chafed at being under the civilian authority of the High Commissioner and hungered for more latitude to conduct what they freely called "punitive" operations. As Dill put it, "The Arabs, like other oriental races, respect strength and determination and regard forbearance as weakness." 18 Both men successively advised that martial law should be declared, with full power handed over to the military for the duration of the uprising. ${ }^{19}$ That this course was not adopted was a sore point for the top brass, but the Colonial Secretary and the High Commissioner concurred instead on a path of using emergency laws (and an Order-in-Council) to confer extensive powers of repression and lawmaking by fiat on Wauchope and other top administrators. When martial law was first mooted in June and dismissed by London, Pierse assented to act in accordance with the doctrine of MACP, as spelled out in the military's 1934 manual, Imperial Policing. ${ }^{20}$ Yet the posture of supporting the "civil power" never satisfied the military, and its leaders waged a post hoc, and eventually a sub rosa, campaign against it.

The failure to defeat the rebels led to serious intermural recriminations. After the termination of the strike the military attributed its inconclusive

${ }^{16}$ Khalili, "Location," 427.

17 Anderson, "From Petition," ch. 7; GOC to Chief of Imperial General Staff (CIGS), 22 Sept. 1936, and 26 Sept. 1936, Liddell Hart Centre for Military Archives (LHCMA), King's College London, Dill papers 2-9.

${ }^{18}$ Report by GOC, pt. IV, BNA, CO 733/317/1.

19 HC to Colonial Secretary (henceforth CSS), 2 June 1936, \#320, BNA, CO 733/311/3; report by AOC (untitled), 46, 95, enclosure to AOC to Air Secretary, 15 Oct. 1936, BNA, CO 733/317/1; and report by GOC, pt. II, in ibid.

${ }^{20}$ HC to CSS, 2 June 1936, \#320; CSS to HC, 3 June 1936, \#242; and HC to CSS, 7 June 1936, \#335, BNA, CO 733/311/3. On the de facto agreement to implement MACP, see memorandum by $\mathrm{HC}$ in response to GOC Dill's report of 30 Oct. 1936 to War Office, 3, enclosure to: HC to CSS, 28 Nov. 1936; and also report by AOC, 48, BNA, CO 733/317/1. 
ending to the squeamishness of the High Commissioner and to the mistaken mission that British forces had been given. The GOC complained in his postmortem report that the Jerusalem government had clung to "a purely defensive policy" that had seen troops "dispers[ed] on defensive duties and abstaining from repressive measures." By forcing "extreme forbearance" on the military, and by obviating the declaration of martial law, the civilian government had squandered an opportunity to restore colonial order and missed the chance of "teaching" the Palestinians a "lesson" that would keep them "quiet for ten years." 21 Wauchope responded by informing the Colonial Secretary that the military had been unable to indicate many examples where the government had improperly restrained its action. Further, he asserted that his underlying motivation had been to preserve the colonial government's post-strike authority. This last, in his view, necessitated some degree of distinction between members of the public who had committed unlawful acts and those who had not, hence his wariness regarding the military's preference for iron fist tactics. $^{22}$

For several months Dill persisted in challenging the doctrine of MACP, which he held pertained to riots, not a full-scale popular rebellion as Palestine had witnessed. He asserted variously that the GOC, not the High Commissioner, should be able to determine when a situation falls under MACP, that the officer commanding should be able to invoke martial law, and that virtually any call-up of the military against an organized foe should trigger a delegation of martial law powers to the officer commanding. ${ }^{23}$ His eagerness on this score, he reiterated, was to allow the military to quickly take all necessary repressive measures to stave off a new uprising without any interference from the civilian government or concern to avoid instilling "bitterness" in the colonized. Wauchope tried to assuage Dill that in the event of renewed revolt his administration would enact a "firmer policy" based on crushing Arab resistance regardless of the cost, but the GOC refused to relent on the issue of being subordinated to the civil power (via MACP) and contended that anything less than martial law was tantamount to neutering the military. ${ }^{24}$

Given the dustup in Palestine, London weighed in with its own determination in March 1937, reaffirming both the supremacy of the High Commissioner and the doctrine of MACP. The High Commissioner, not the

\footnotetext{
21 Report by GOC, pts. I, II, and IV, BNA, CO 733/317/1; "chance" quote in GOC to CIGS, 10 Nov. 1936, LHCMA, Dill papers 2-9.

22 HC to CSS, 13 Nov. 1936; and Memo by HC on GOC Dill's report, 8, 10, enclosure to HC to CSS, 28 Nov. 1936, BNA, CO 733/317/1.

${ }^{23}$ Memorandum by GOC, n.d., enclosure to HC to CSS, 26 Jan. 1937, "Secret A," BNA, FO (Foreign Office) 371/20804.

24 Note of a discussion, HC with GOC, 26 Nov. 1936; and GOC to HC, 14 Dec. 1936, enclosure to HC to CSS, 26 Jan. 1937, "Secret A," BNA, FO 371/20804.
} 
GOC, was empowered to decide when the military would be called into action to protect the administration and retained the ability to modify military plans if he judged they would have adverse political or religious impacts. The Cabinet endorsed Wauchope's promise to more vigorously stamp out any recrudescence of rebellion and established that the High Commissioner could choose, in lieu of declaring martial law, to delegate certain powers to the GOC, retaining power and jurisdiction himself over all other areas. Shortly after the Cabinet's pronouncements, Wauchope did propose, in view of a bubbling mini-offensive against Jewish colonies and targets in early 1937, to delegate authority over the Galilee to the military, but Dill rejected the idea, deeming the situation more appropriate for the police to handle while stubbornly insisting that any delegation of powers to the military should not be geographically limited. ${ }^{25}$ This disposition, with London in support of MACP and the High Commissioner's authority and the GOC subdued but disagreeable, held until the second phase of the revolt, when the debate over military control was reopened.

\section{ASCENT OF THE REVOLT, 1937-1938}

The second phase of the revolt, primarily triggered by the Peel Commission's recommendation in mid-1937 for the partition of Palestine and the creation of a Jewish state, was greater in scope and intensity than the first phase. Over many months of fighting the British government lost control of much of the country. As the rebellion gathered momentum, colonial forces retreated to fortified military bases and to a handful of principal urban centers where rebels continued to contest and challenge their authority. The rebels established their own governing institutions, including courts and administrative capacities, to rule over the public, signaling their intention to eject and replace the British regime. ${ }^{26}$ Although British forces easily outgunned the insurgents and regularly defeated them on the battlefield, the rebellion continued to grow and expand. The colonial authorities searched in vain from autumn 1937 to autumn 1938, throughout the period of the rebellion's regeneration and ascent, for means by which to quell the budding anticolonial revolution.

When the rebellion began again in September 1937 with the assassination of Lewis Andrews, Acting District Commissioner for the Galilee, the government quickly tried to smother it. The visible leadership bodies of the 1936 general strike, the urban-based national committees and the overarching Arab Higher Committee (AHC) that coordinated their efforts,

25 CSS to HC, 15 Mar. 1937, Cabinet paper (CP) 95 (37); and HC to CSS, 27 Mar. 1937, CP 109 (37), BNA, FO 371/20805.

26 Charles Anderson, "State Formation from Below and the Great Revolt in Palestine," Journal of Palestine Studies 47, 1 (2017): 39-55. 
were banned and their members targeted with preemptive arrests. Over eight hundred men were detained and held without trial under emergency law in prisons and prison camps, while hundreds if not thousands of others fled abroad to escape the same fate. ${ }^{27}$ Colonial Secretary William Ormsby-Gore suggested that powers be immediately delegated to the new GOC, A. P. Wavell, but Acting High Commissioner William Battershill and the GOC demurred, believing that they had the situation in hand. ${ }^{28}$

In November, a military court system was erected and given jurisdiction over offenses related to state security. Carrying firearms or bombs was made a capital offense and procedure at these courts was cursory, with crossexamination of witnesses, for example, routinely disallowed. ${ }^{29}$ Police billets were established in some eighty villages proximate to rebel activities at their residents' expense and both villages and urban centers were hit with collective fines to disincentivize and penalize cooperation with "terrorists." 30 Additionally, as they had in 1936, the police and the military conducted searches of villages and urban quarters. Although their official purpose was to arrest rebels, seize arms, and deny insurgents sanctuary among the public, in reality search operations were another form of collective punishment and typically amounted to violent rampages. Some were punctuated by killings or executions by the security forces, but as a rule they entailed the destruction of local foodstuff reserves along with all manner of personal property, from crockery to bedding and furniture to entire homes or shops. ${ }^{31}$ Many in the government were convinced that the crux of the rebel organization resided in Syria and Lebanon, where nationalists associated with the ousted Mufti and head of the AHC, al-Hajj Amin al-Husayni, had escaped into exile and were endeavoring to command the rebellion from afar. $^{32}$ A good deal of emphasis was thus placed on the northern border, where an 80-kilometer fence (known as "Tegart's wall") and newly built police posts were aimed at interdicting weapons smuggling activity and insurgent movement across the frontier. ${ }^{33}$

27 Report to the League of Nations on the Administration of Palestine and Transjordan, 1937, 14; Akram Zu'aytir, Yawmiyat Akram Zu'aytir: al-Haraka al-Wataniyya al-Filastiniyya, 19351939 (Beirut: Mu'assasat al-Dirasat al-Filastiniyya, 1980), 336.

28 CSS to Officer Administering the Government (OAG, i.e., the Acting High Commissioner), 29 Sept. 1937, BNA, CO 733/332/11; OAG to CSS, 30 Sept. 1937, BNA, FO 371/20815.

29 Report to the League of Nations, 1937, 13; Bahjat Abu Gharbiyya, Fi khidam al-nidal: mudhakkirat Bahjat Abu Gharbiyya (Beirut: Mu'assasat al-Dirasat al-Filastiniyya, 1993), 115.

${ }_{30}$ Report to the League of Nations, 1937, 11-12, 14; fines in BNA, CO 733/332/10.

31 See Norris, "Repression"; Hughes, "Banality"; Anderson, "From Petition," chs. 7, 9, and 10; and Kelly, Crime of Nationalism, chs. 2-4.

32 See Anderson, "From Petition," ch. 9 on the rebel leadership, and pages 852-53 and 909-11 on official views.

33 Report to the League of Nations, 1937, 14-15; Note of meeting with Chief Secretary, 31 Dec. 1937, enclosure to Chief Secretary to Inspector General of Police, 5 Jan. 1938; and Meeting on 
In the first months of the revolt's renewal, the government in Jerusalem reported to the Colonial Office that "neither life nor property is safe in certain parts of Palestine," yet maintained that the Arab population was generally disinterested in unrest, in no small measure because it was awed by the government's "extreme" repression and the punishment of villages alleged to "shelter malefactors." 34 The impression of the rebellion's weakness was accentuated by a series of punishing routs it suffered on the battlefield between December 1937 and March 1938, each of which cost the rebels eighteen to thirty men or more. ${ }^{35}$ Nevertheless, despite their defeats in combat the rebels continued to mass in considerable numbers, with, for example, insurgent commander Shaykh 'Atiya Ahmad 'Awad's camp estimated in February at between 120 and three hundred men. ${ }^{36}$

Human shields were reintroduced in the second phase of the revolt during the government's effort to regain control of the strategic Latrun region connecting Jerusalem and Jaffa/Tel Aviv. By early 1938 Arab irregulars were raining down "constant attacks" on Jewish traffic in the area. At a meeting of the colonial state's presiding civilian and military officers with Charles Tegart, a counterinsurgency specialist and veteran of colonial policing in Bengal, and David Petrie, former director of intelligence in India, both of whom were brought in to ramp up the government's campaign to crush the rebellion, the use of human shields was sanctioned. Security forces in the Latrun were authorized to seize residents from villages in the vicinity of sniping activity and force them to accompany local patrols. The introduction of human shields had something of the desired effect, dampening the sniping prevalent in the region. ${ }^{37}$

In many ways the Latrun episode presaged the shape of things to come, both in that the roadways became a critical battleground in the contest for control of the country and in that the military ultimately resolved to use human shields to stem the flow of assaults on transportation convoys and arteries. As in many guerilla campaigns, the relative vulnerability and strategic importance of the transportation network was seized on by the rebels, who assailed British and Jewish traffic and sabotaged the railroads with great regularity. By disrupting and endangering transit lines, the rebels

public security, 7 Jan. 1938, Middle East Centre Archive, St. Antony's, Oxford (henceforth MECA), Tegart papers, 2-3.

${ }_{34}$ OAG to Shuckburgh (CO), 21 Nov. 1937, CP 286 (37), BNA, CO 733/332/12.

35 Anderson, "From Petition," 887-88, 918-22.

${ }^{36}$ Royal Air Force (Jeru.), 17 Mar. 1938, February operations, BNA, Air 5/1248. Shaykh 'Atiya was a disciple of the radical preacher 'Izz al-Din al-Qassam, whose death at the hands of British police in 1935 helped ignite the Great Revolt. He was killed in March 1938 at the battle of Yamun.

${ }^{37}$ Report to the League of Nations, 1938, 6; Meeting on public security, 7 Jan. 1938, MECA, Tegart papers, $2-3$. 
were able to attenuate the colonial state's ability to project its political authority and military power across space, not least since the counterinsurgency relied on the same roads and railways to move men and materiel. At the same time, harassing Jewish traffic played havoc with the economic health and demographic growth of the yishuv (the pre-state Jewish community), damaging the settler enterprise's international image and slowing its expansion. $^{38}$

True to his pledges of a year earlier, the High Commissioner did not stand in the way of the military after the renewal of the revolt. Nevertheless, Wauchope was discredited and nicknamed "washout."39 Where Wauchope had believed that British rule depended on preventing a "fight to the finish" and the damage that would follow, this was precisely the fight that military commanders were spoiling for. ${ }^{40}$ For them, Palestine recalled the rebellious frontiers of the empire, "sites of chronic battles, expeditions, and punitive military measures."41 MACP, which was associated, like Wauchope, with the failure to break the revolt in 1936, was ill-suited for such circumstances. Quickly, but informally, the military dispensed with the core MACP principle of subordination to civilian government and two of three subtending components of the doctrine, namely the requirement to accomplish objectives with a minimum amount of force and the need to maintain military-civilian cooperation. ${ }^{42}$ The erosion of civilian control was felt immediately. Not only did commanders license dramatic displays of force, but the military also evaded civilian oversight by failing to accurately report and account for some of its most audacious violence. For example, during a search at Silwan on the southern outskirts of Jerusalem in November 1937, the official account holds that one villager was shot dead and another wounded. By contrast, an Arab account put the toll at no less than five residents killed and seventy hospitalized while houses were set ablaze, yet one serviceman's diary tells an even more sordid story in which

\footnotetext{
38 Jewish immigration dropped from a peak of over sixty thousand in 1935 to 10,500 in 1937 , yet with emigration factored in net immigration was down to 4,460 that year. See Anderson, "From Petition," 847. For a contemporary point of comparison on the importance of attacking roadways in insurgencies, see Thomas E. Ricks, Fiasco: The American Military Adventure in Iraq (New York: Penguin, 2007 [2006]), 217-20, 303-5, 415.

39 Hughes, "Banality," 319.

40 HC to CSS, 4 Sept. 1936, CP 238 (36), BNA, CO 733/297/5.

41 Khalili, Time, 19. Tegart and Petrie agreed that conditions in Palestine resembled those in the Northwest Frontier Province. Gad Krozier, "From Dowbiggin to Tegart: Revolutionary Change in the Colonial Police in Palestine during the 1930s," Journal of Imperial and Commonwealth History 32, 2 (2004): 115-33, 124.

42 Johnson, "Command," 574. The other essential principle of MACP, which was not violated in the Great Revolt, was the need for "firm and timely action" in response to rebellious activity. On the highly contentious issue of "minimum force," see Charles Townshend, "Martial Law: Legal and Administrative Problems of Civil Emergency in Britain and the Empire, 1800-1940," Historical Journal 25, 1 (1982): 167-95.
} 
troops beat twelve residents to death with rifle butts. ${ }^{43}$ Similarly, according to one British policeman in early 1938, soldiers near Jenin massacred as many as sixty surrendering rebels in an incident that was never officially recorded. ${ }^{44}$ Soldiers also sometimes killed those acquitted at the military courts or other "suspects," using pretexts to justify the executions. ${ }^{45}$ Complaints of outrages by both the police and the military appeared so steadily that by 1938 the Anglican Bishop in Jerusalem accused the government of fighting terrorism with terrorism. ${ }^{46}$ Reacting to the charges, the police sought to have the army restricted to cordons and withdrawn from searches in some locales. ${ }^{47}$

The military's resort to off-the-books conduct, and to atrocities, represented a clear, if sub rosa, repudiation of the civil power's authority. This tendency continued even after Wauchope was replaced in March 1938 by Harold MacMichael, a former governor of Tanganyika who enabled the progressive militarization of the Mandate. Within some two months of taking office MacMichael concluded that "every Arab must be regarded as a potential enemy in certain eventualities." 48 Nevertheless, his insistence on maintaining civilian control of the government was anathema to the military, which continued to blame the civil administration for the revolt's resurgence and subsequently mounted a second effort to directly take control of the Mandatory government.

By early 1938, the rebels had circumvented the countermeasures designed to deny them men and territory, but rebel bravado during this rebuilding phase had been costly. ${ }^{49}$ The reality that large numbers made them more conspicuous without at the same time translating into battlefield advantage precipitated a set of changes in rebel organization and tactics. Beginning in March, rebel commanders began to break their fighters into smaller formations that could be supplemented by large reserve forces during combat. ${ }^{50}$ The insurgents' shift to smaller fighting units roughly coincided with an increase in rebel activity, including sabotage operations, transit assaults, and attacks on military bases, police posts, and Jewish colonies. ${ }^{51}$

43 Narrative dispatch \#3, OAG to CSS, 18 Nov. 1937, 13-14, BNA, CO 935/21; Abu Gharbiyya, Fi khidam, 106; Hughes, "Banality," 346.

44 Hughes, "Banality," 330.

45 Ibid., 347.

46 Bishop Graham-Brown to Miss Blyth, 21 Jan. 1938; and notes on visit to Beit Iksa, 16 Feb.

1938, MECA, Jerusalem and East Mission papers (JEM) 61-3.

47 Wainwright (police) to [Jerusalem] District Commissioner (DC), 19 Feb. 1938; and enclosure, MECA, JEM 61-3.

48 HC to CSS, 25 May 1938, \#232, BNA, CO 733/367/1.

49 See Anderson, "From Petition," ch. 9.

50 "Gangs-Northern Sector," n.d., MECA, Tegart papers, 2-3. This applied to the formations of 'Abd al-Rahim al-Hajj Muhammad, who became the revolt's preeminent commander in its second phase, and of Yusuf Abu Durra and 'Arif 'Abd al-Raziq, both of whom were also leading rebel figures.

51 Report to the League of Nations, 1938, 8-10; Tegart, no heading, 10 May 1938, MECA, Tegart papers $2-3$. 
As the rebellion deepened and spread, the Mandatory slid into crisis. Before his replacement in April, GOC Wavell conceded that the counterinsurgency had come up short: "In the intervals between military operations on a large scale, which only have a temporary effect, there is little civil control of the disturbed areas, many of which are somewhat remote and inaccessible." Tegart was more emphatic about the situation. He called the preservation of colonial law and order a "disheartening task" and concluded in early May: "It seemed quite obvious that our present methods of dealing with the situation have definitely failed. We remained continually on the defensive, reacting to attacks by the enemy and were, in consequence, steadily losing ground." ${ }^{, 52}$

In May Tegart orchestrated the occupation of a dozen and a half villages that he believed were epicenters of rebel activity. ${ }^{53}$ The plan had little of its intended effect: sabotage operations and road attacks near the occupied villages immediately increased, rebels assailed or intimidated Palestinian villagers cooperating with the British, and military encampments in occupied villages were repeatedly attacked while, according to the Jewish Agency, insurgents used their powers of disguise to continue to recruit cadres from the very same occupied villages. ${ }^{54}$ Somewhat more successful than Tegart's village occupation scheme was the fielding of irregular British-Jewish military units known as the Special Night Squads (SNS), whose most notable veterans later went on to form the core of the Israeli army. First headed by the eccentric Christian fundamentalist Orde Charles Wingate and tasked with curbing the growing campaign of sabotage directed at the Iraq Petroleum Company (IPC) pipeline that transited northern Palestine, the SNS became infamous for brutal attacks on villages, often conducted at night, and for the intimidation and random execution of villagers. Although they temporarily succeeded in cutting pipeline sabotage from eighteen incidents in June to three in July (before a new rebel offensive in September and October), they did little to halt the growth of the rebellion. ${ }^{55}$

The High Commissioner informed London in May that the position was becoming grave. Although southern Palestine was relatively "quiet" (with the exception of Hebron), "The rest of the country to the north ... especially

${ }^{52}$ GOC to War Secretary (WSS), 7 Apr. 1938, 12, BNA, CO 733/379/3; Tegart, memo: "Present Situation," 3 May 1938; and Tegart, no heading, 10 May 1938, MECA, Tegart papers 2-3.

53 Tegart to Chief Secretary, 5 May 1938, MECA, Tegart papers 2-3; narrative dispatch \#8, HC to CSS, 14 July 1938,38 , BNA, CO 935/21.

${ }^{54}$ GOC to WSS, 24 Aug. 1938, 2, BNA, WO 32/9497; Zu'aytir, Yawmiyat, 400, 402, 403; Political information on Arab activities: survey, 6 July 1938, 17-18, Central Zionist Archive (CZA) S/25-22191.

${ }_{55}$ Matthew Hughes, "Terror in Galilee: British-Jewish Collaboration and the Special Night Squads in Palestine during the Arab Revolt, 1938-39," Journal of Imperial and Commonwealth History 43, 4 (2015): 590-610; Report to the League of Nations, 1938, 10-11; CID (Criminal Investigation Department, police), situation reports for Sept. and Oct., MECA, Tegart papers 1-2. 
Nablus sub district and the whole of Galilee district is subject to domination by gangs composed of local and foreign elements which constantly commit outrages against life and property." The erection of the frontier fence and the new police posts in the upper Galilee had drained security personnel from the south, leaving it vulnerable, while British forces were overextended and being run ragged by round-the-clock operations. Three weeks later, MacMichael requested military reinforcements. ${ }^{56}$

The considerable growth of rebel power in the country was all the more remarkable for the minimal number of British and Jewish lives taken in the process. In the first six months of 1938 the rebels only claimed eleven British lives while injuring another thirty-four. Casualties inflicted on Jews were worse, but not vast, with thirty-eight killed and 116 injured. Compared with the sheer number of attacks they unleashed-358 episodes of firing on military and police, 131 murders or attempted murders, 223 attacks on Jewish colonies, and another 115 assaults on transportation - the human toll exacted by the rebellion from the colonial power and the yishuv was decidedly modest, if not meager. ${ }^{57}$ Yet despite its low degree of lethality the rebel campaign had, in a stunning fashion, impaired British control over half of Palestine.

The new GOC, R. H. Haining, had two principal explanations for this turn of events. For one, he acknowledged that the single division of troops on hand was inadequate to quell the uprising. Yet privately he railed against the "second rate administration" in Jerusalem which was prone to "defeatist" ideas, singling out High Commissioner MacMichael for his "Olympian" and impersonal manner of leadership and his tendency, as with Wauchope before him, to downplay the revolt while expecting the military to rescue the administration. Haining rejected what he saw as the civil administration's shirking of its own responsibilities and favored a system of military control over the country, albeit not through martial law, but rather via the appointment of regional military governors. As in 1936, the aim of such a plan was, despite the GOC's claims to want to support the civilian administration, in fact to supersede it and terminate its ability to check or restrain the military's conduct, and it was for precisely this reason that he expected the High Commissioner would block any serious proposal to delegate powers to the GOC. ${ }^{58}$ Remarkably, the dispute between the civil and military branches was loud and indiscrete enough to come to the attention of the Palestinians in summer 1938, some of whom were fully aware of its extent and of the military's desire for total control. ${ }^{59}$

${ }^{56} \mathrm{HC}$ to CSS, 25 May 1938, \#232; and 13 June 1938, BNA, CO 733/367/1; GOC to WSS, 24 Aug. 1938, 6-7, BNA, WO 32/9497.

57 HC to Deputy Colonial Undersecretary (Shuckburgh), 5 July 1938, BNA, CO 733/366/4.

58 GOC to Tegart, 25 June 1938, and 31 July 1938, MECA, Tegart papers 4-4.

59 Darwaza, Mudhakkirat, vol. 3, 563. 
The insurgents' fighting capacities, battlefield tactics, and internal organization all improved as their power grew. The High Commissioner highlighted this in mid-July: "It is notable that during the last three months the tactical skill of the armed bands has developed. They now operate according to plan and under leaders whose instructions they understand, trust and obey; they have, as is only natural, excellent "intelligence"; and many of the schemes owe such local success as they have achieved to a discipline and sense of guerilla tactics which are, I am informed, more marked today than they were, for instance, in the concluding stages of the disturbances of 1936." 60 The increasing skill and effectiveness of rebel attacks was paired with a bold series of offensives in which rebels surged into urban spaces and illustrated the weakness of colonial control over the few areas of the country where the government still had a tangible presence.

In Nablus two "well-organized and executed" operations in August spirited away P£7200 from Barclays Bank. At Hebron rebels soon carried out an even more impressive raid, torching the Barclays branch (after finding it empty), ransacking the police station and the post office, and capturing police officers (killing one), before being carried aloft by supportive crowds and then escaping unharmed. ${ }^{61}$ The same month a lone gunman, 'Ali Ahmad Mustafa, nicknamed "the gazelle" for his speed, slipped into the wellguarded government compound in Jenin and slew the city's notoriously harsh governor, Walter Moffat. Mustafa was killed in the incident, but the assassination "created a profound impression throughout the country" and reinforced the colonial regime's distrust of its own Arab government employees. $^{62}$

In September, 'Abd al-Halim al-Jawlani, a mastermind of the rebellion in the country's south, spearheaded the next set of raids. Leading a party estimated at five hundred strong in a disciplined operation at Beersheba where the public greeted them with rose water and ululations, his men destroyed the wireless station, raided the police station and its armory, and freed all the prisoners in the town jail. Days later at Bethlehem, a party of 150 laid waste to the town's police station, post office, and municipal offices. In successive raids on Beersheba, Bethlehem, Jericho, and Ramallah, the government's defenses collapsed with remarkable ease and the rebels carried out their missions without meeting any serious resistance. The mounting wave of attacks across the south caused the government to withdraw its police forces and abandon

\footnotetext{
60 Narrative dispatch \#8, HC to CSS, 14 July 1938, 38, BNA, CO 935/21.

61 Narrative dispatch \#9, HC to CSS, 13 Sept. 1938, 49, BNA, CO 935/21; Details of events in Hebron, 25 Aug. 1938, CZA S/25-22191.

${ }^{6}$ Subhi Yasin, al-Thawra al- 'Arabiyya al-kubra fi Filastin, 1936-1939 (Cairo: Dar al-Huna li1-Taba'a, 1959), 152-53; HMS Malaya, 28 Aug. 1938, BNA, CO 733/366/4; narrative dispatch \#9, HC to CSS, 13 Sept. 1938, 49, BNA, CO 935/21; Kelly, Crime, 126.
} 
police stations everywhere except for at heavily reinforced locations in Hebron and Gaza city. ${ }^{63}$

The most gruesome episode of the urban offensive occurred at Tiberias in the north. In early October rebels blockaded the town, took down all its communications lines, and then raided and destroyed government centers, as they had elsewhere. The insurgent party of some three hundred, singing anthems, also assaulted the town's Jewish quarter, where they massacred residents, killing nineteen, including women and children. The day after their incursion, government forces claimed to locate the insurgents responsible for the carnage and inflicted fifty-nine casualties in three separate encounters. The SNS also exacted its own brand of justice, summarily executing ten men at the village of Hittin, west of Tiberias. ${ }^{64}$

The same month, in an ostentatious display of the insurgency's daring, rebels retook the Old City of Jerusalem from the British regime. During the ancient city's would-be liberation insurgents engaged the police, burned down the local police station, sniped the Jewish quarter, and waged a minicampaign against collaborators. The temporary capture of the symbolic heart of Palestine, immediately proximate to the seat of the colonial government itself, was reversed by a week-long siege that killed some twenty Palestinians, seven of whom were said by Zionist intelligence to have starved to death during the strenuous curfew enacted by the government. ${ }^{65}$

At Jaffa, rebel influence was not the result of a singular movement. In August, the rebels ringed Tel Aviv while imposing a sartorial edict in Jaffa compelling the Arab public to wear the headdress of peasants (the kaffiyya), thus lending the insurgents further disguise. They attacked and intimidated the local police, raided the central station's armory, and went about erecting governing institutions, such as revolutionary courts, that exercised authority over the Arab population. Even after major counterinsurgent operations there in November, the High Commissioner referred to Jaffa as a "hotbed of terrorism." $" 66$

63 HMS Malaya, 15 Sept. 1938, BNA, CO 733/366/4; Zu'aytir, Yawmiyat, 447; narrative dispatch \#10, HC to CSS, 24 Oct. 1938, 57-59, BNA, CO 935/21; Royal Air Force (Jeru.), 20 Oct. 1938, September operations, BNA, Air 5/1248.

64 Official communiqué \#2, General Command of the Army of the Arab Revolution in Palestine, n.d., in Watha'iq al-haraka al-wataniyya al-Filastiniyya, 1918-1939: min awraq Akram Zu'aytir, Bayan al-Hut, ed. (Beirut: Mu'assasat al-Dirasat al-Filastiniyya, 1984), 508; Report to the League of Nations, 1938, 15; narrative dispatch \#10, HC to CSS, 24 Oct. 1938, 62-63, BNA, CO 935/21; John Knight, "Securing Zion? Policing in British Palestine, 1917-39," European Review of History 18, 4 (2011): 523-43, 534. As the colonial authorities later acknowledged, it was unusual that the rebels intentionally attacked women and children: HC to CSS, 5 July 1939, BNA, CO 733/398/1.

65 Abu Gharbiyya, Fi khidam, 111; The situation in Jerusalem's Old City, 23 Oct. 1938; and Army action in the Old City on 21-24 Oct. 1938, CZA S/25-22191; HC to CSS, 17, 18, and 19 Oct. 1938, \#694, \#699, and \#708, BNA, CO 733/366/4; narrative dispatch \#11, HC to CSS, 3 Dec. 1938, 72, BNA, CO 935/21.

66 Discussion on security (extracts), 24 Aug. 1938, MECA, Tegart papers 2-4; surveys, 19-25 Aug. 1938, 2-8 Sept. 1938, CZA S/25-22437; Exchanging the tarbush, 30 Aug. 1938; and Security 
The rebel capture of the Old City of Jerusalem in October triggered a version of military control. As the GOC predicted, during a set of important discussions in London regarding British strategy the High Commissioner opposed devolving authority to the military, denigrating martial law as the "temporary negation of all law" and emphasizing the need for more troops above all. The War Office countered by calling for an end to the civilian control of the colonial regime, branding it a hindrance to the restoration of order. Colonial Secretary Malcolm MacDonald strove to give the military a semblance of what it desired without allowing it to compromise his plan to use negotiations and limited concessions to the Palestinians to curtail the Arab uprising (which yielded the 1939 Roundtable talks and White Paper). Though he doubted its constitutionality, he pushed through the delegation of powers, subordinating district officials to the military and giving the latter control over the Defence Regulations that formed the legal basis of the counterinsurgency, but without fully displacing the High Commissioner. ${ }^{67}$ When he learned of these plans, Haining protested that the situation in the country had become so dire that the civil administration was incapable of action. Disparaging the hybrid authority created by the delegation of powers, the GOC claimed that "dual control" was unacceptable and "demanded instead plenary powers for the military." The Colonial Secretary tried to reassure Haining that the military was to be given a free hand in suppressing the rebellion while reaffirming that "it is undesirable to turn Palestine into an area of unrestricted military control." Haining was unmoved and contended that any strategy of concessions to the Arabs would fail. The Colonial Secretary was left in the odd position of pressing forward without the full agreement of the military in Palestine, delegating powers to it while simultaneously reopening a diplomatic track with Palestinian leaders. ${ }^{68}$

Haining persisted in asserting the need for a military government as late as summer 1939, even after he declared the revolt all but dead. Frustrated in his drive for total control, the GOC regarded MACP as "that most difficult of situations" and condemned dual control as a "contradiction in terms." 69

situation in Jaffa, 5 Sept. 1938, CZA S/25-22191; HMS Malaya, 8 Sept. 1938, BNA, CO 733/366/ 4; narrative dispatch \#11, HC to CSS, 3 Dec. 1938, 74, BNA, CO 935/21. Rebels subsequently extended the kaffiyya edict throughout the country.

${ }^{67}$ Palestine: Discussions, Oct. 1938 - first meeting, 7 Oct. 1938, second meeting, 7 Oct. 1938, and third meeting, 8 Oct. 1938; CSS to OAG, 8 Oct. 1938, \#466; all at BNA, FO 371/21864. Quote from the first meeting. On MacDonald's diplomatic plans, see Anderson, "From Petition," 1094 115; Norris, "Repression," 30; and Porath, Palestinian Arab, ch. 10.

68 OAG to CSS, 9 Oct. 1938, \#672; CSS to OAG, 10 Oct. 1938, secret; CSS to OAG 10 Oct. 1938, \#480 (quote); OAG to CSS, 11 Oct. 1938, \#384 [sic]; and HC to CSS, 18 Oct. 1938, \#698, BNA, FO 371/21864.

${ }_{69}$ Respectively: GOC to Tegart, 6 July 1939, MECA, Tegart papers 4-4; GOC to WSS, 24 Apr. 1939, 11, BNA, WO 32/9499. 
Although MacMichael covered up military atrocities and perennially defended the conduct of the counterinsurgency, cooperation between military and civilian leaders, especially in the north, deteriorated after major military reinforcements arrived in the country in October 1938, following the Munich Pact and the appeasement of Hitler. Moreover, while military commanders continued to take wide latitude in dispensing punishment to Palestinians, whether combatants or civilians, a degree of insubordination and internal indiscipline also surfaced within the military as Haining proved in some cases incapable of fully controlling his own subordinates. ${ }^{70}$

\section{WAR OF THE MINES}

Much to the consternation of the military, the rebels continued to make a point of avoiding head-on encounters as the uprising hit its fullest stride. Ambushes, sniping attacks, and the skillful deployment of mines posed a daily problem for the colonial government, the military, and the yishuv by summer 1938. During the second half of the year the insurgents' offensive operations nearly doubled in number and their lethality more than quadrupled. Attacks on motorized transit nearly doubled, and sabotage of the railroads tripled. ${ }^{71}$ To keep from killing fellow Arabs, the rebels issued warnings not to travel in affected areas, especially at night. ${ }^{72}$ It was in this fraught context that the military began the systematic use of human shields.

August marked a sharp escalation in transit attacks. Four Jews were killed and thirteen were injured in mine attacks in the citrus-growing regions of the coastal plain. Seven Jewish workers were killed and seven more injured by a mine near Tulkarm early in the month. A deadly ambush on Mt. Carmel in the Haifa region saw rebels kill at least eight Jews, some of whom were supernumerary police. ${ }^{73}$ Mid-month the police reported, "Eleven casualties are the result of landmines, the most dangerous form of attack and the greatest menace to public safety." Eight British soldiers were killed and

${ }^{70}$ Edward Keith-Roach, Pasha of Jerusalem: Memoirs of a District Commissioner under the British Mandate (New York: Radcliffe Press, 1994), 193, 195; Scrivenor, Haifa diary 1938-39, entries for 11 and 14 Nov. 1938, and 21 Dec. 1938, Bodleian Library, Oxford (BLO), Scrivenor papers. The key offender against military discipline was General Bernard Montgomery, divisional commander of northern Palestine as of October 1938 and later of al-Alamein fame.

71 HC to Deputy Colonial Undersecretary, 2 Feb. 1939, BNA, CO 733/398/2; HC to Deputy Colonial Undersecretary, 5 July 1938, BNA, CO 733/366/4. See also Report to the League of Nations, 1938, 19. Officially there were 628 attacks on military and police, 428 on Jewish colonies and urban quarters, and 220 on transportation in the second half of the year (compared to 358,223 , and 115 , respectively, for January through June), which took a human toll of sixtythree British and 172 Jewish deaths (as against eleven and thirty-eight in the first half of 1938).

${ }_{72}$ Zu'aytir, Yawmiyat, 391; Information from Nablus, 27 June 1938, CZA S/25-22191.

73 Report to the League of Nations, 1938, 12; HC to CSS, 5 Aug. 1938, \#430; and 16 Aug. 1938, \#463, BNA, CO 733/366/4; CID, Situation report, 9-16 Aug. 1938, MECA, Tegart papers 1-2. 
another twenty-four were injured in one week, making it one of the worst for the British military in Palestine, if not the worst, since World War I. A concerted effort was also made to sabotage the rail system, and six trains were derailed during the month. ${ }^{74}$ The Palestine government responded to the escalation of rebel assaults on transit by banning the use of all nonmunicipal roads throughout the country between the hours of 6:00 p.m. to 4:00 a.m. In September the government also forbade anyone from approaching within a mile of the rail line linking Haifa to Egypt. ${ }^{75}$

The rebels boasted of the effectiveness of mines and often exaggerated their deadliness. One rebel broadsheet in August carried an item claiming that thirteen British soldiers were killed by a mine on the Acre-Haifa road. According to official records, the incident, near al-Sha'b in the Acre subdistrict, actually killed one officer, who was a lieutenant. ${ }^{76}$ The military declared internally that it would retaliate by "blowing up" the village, but first it beat villagers, men and women alike, at al-Sha'b and at nearby alDamun and al-Birwa, and seized 182 men. While marching their detainees to lock-up at al-Rama village, the arrest party was attacked by rebels who managed to free 132 prisoners. ${ }^{77}$ Outraged at this brazen feat, local military units quickly turned to coffeehouses and markets in Acre as well as nearby villages, and after more beatings, dragged members of the Arab public away willy-nilly for use as human shields on the roadways. As in other instances of human shielding, such hostages were forced to accompany military convoys, patrols, and escorts for civilian traffic, and were emplaced at the front of vehicles, on planks or tied to their hoods, where they were left without any physical protection and where they were almost certain to become casualties in the event of a mine or sniping attack. ${ }^{78}$ The next day the military returned to al-Sha'b, but the rebels had again laid an ambush for them. A major encounter ensued that cost the British three lives while the rebels lost thirty-seven men. The government dynamited some 120 of the village's roughly three hundred homes as punishment, while perhaps an equal number were also damaged or destroyed in the process. Not content with this, the army conducted successive assaults on al-Sha'b and

\footnotetext{
74 CID, Situation report, 16-23 Aug. 1938, MECA, Tegart papers 1-2; Report to the League of Nations, 1938, 12.

${ }_{75} \mathrm{HC}$ to CSS, 21 Aug. 1938, \#475; and HMS Malaya, 8 Sept. 1938, BNA, CO 733/366/4.

76 Al-Jihad \#2, repr. in Watha'iq al-haraka, 488; HC to CSS, 17 Aug. 1938, \#466, and HMS Repulse, 27 Aug. 1938, BNA, CO 733/366/4; Bridgeman to bishop in Jerusalem, 29 Aug. 1938, MECA, JEM 61-3.

77 Acting DC-Galilee to Chief Secretary, 2 Sept. 1938, BLO, Blackburne papers 3-2; HMS Repulse, 27 Aug. 1938, BNA, CO 733/366/4; Operations of the mujahidin in the north, 13-16 Aug. 1938, in Watha'iq al-haraka, 492; and letter from Acre, 17 Aug. 1938, in ibid., 496.

78 Norris, "Repression," 34; Hughes, "From Law and Order," 15.
} 
surrounding villages in the aftermath, leading many villagers to decamp to Acre in search of safety. ${ }^{79}$

The seizure of members of the Arab public for use as human shields during the Sha'b episode in August was coincident with the regularization of the tactic in many areas of the country. In reporting the movement of a howitzer battery from the northern border to Beisan, the navy captain in charge remarked: "The whole line was proceeded [sic] by what is now known as a 'Minesweeping Taxi.' These are Arab 'bad-Hat' taxis and driver [s], a number of them having recently been commandeered. They are kept under guard at the R.A.S.C. Depot and are used to precede all convoys. This stratagem is hoped to reduce land mine casualties." The use of human shields was soon codified into official regulations that stipulated their use for all military convoys and for night transit. Available evidence strongly suggests that at least as far as the roadways they were first used in the north and central highlands regions, and later extended to the country's south. ${ }^{80} \mathrm{~A}$ colonial official posted to the Galilee later facetiously explained that "Roads [,] particularly village tracks, were always liable to be mined, but, in the paradoxical way things work in the Arab world, there was never any shortage of volunteers among the local taxi owners prepared to drive immediately ahead of a military column and thereby, in some degree, to ensure its safety." In actuality, as one howitzer commander admitted, "The new regulations whereby each convoy is preceded by two 'minesweepers' is not much appreciated by the prisoners." He describes the procedure in more unvarnished terms: "On each occasion the car is filled with them, lashed together and with little room to move. On most occasions they are put in at the point of a revolver and there they stay from about 2100 until about 0430." ${ }^{81}$ Hostages were at risk after completing stints as shields as well, especially those not in separate cars, who were sometimes thrown violently from their vehicles by British drivers careening about or stomping on the brakes. Palestinians ejected in this manner might be run over and either

79 Letters from Acre, 17 and 27 Aug. 1938, in Watha'iq al-haraka, 496, 499-500; Royal Air Force (Jeru.), 17 Sept. 1938, August operations, BNA, Air 5/1248; Zu'aytir, Yawmiyat, 435-36; Bridgeman to bishop, 29 Aug. 1938, MECA, JEM 61-3.

${ }^{80}$ HMS Malaya, 28 Aug. 1938, and 2 and 15 Sept. 1938 (appendix II), BNA, CO 733/366/4; Thomas M. Ricks, ed., Turbulent Times in Palestine: The Diaries of Khalil Totah, 1886-1955 (Jerusalem and Ramallah: Institute for Palestine Studies and PASSIA, 2009), 231; Perrott to (Southern Divisional Commander) O'Connor, 18 Oct. 1938; and GOC to O'Connor, 6 Nov. 1938, LHCMA, O’Connor papers 3-2; O’Connor to Wetherall, 22 Jan. 1939, LHCMA, O'Connor papers 3-4. Quote from the first report; note of human shields (referred to by euphemism) being made regulation is in the last HMS Malaya report and last O'Connor letter.

81 Sir Gawain Bell, Shadows on the Sand: The Memoirs of Sir Gawain Bell (London: Hurst and Co. with St. Martin's Press, 1983), 94; HMS Malaya, 15 Sept. 1938 (appendix II), BNA, CO 733/ $366 / 4$. 
killed or left for dead. ${ }^{82}$ Human shields were also deployed on the railways, where they were put in special cars or trollies that ran ahead of trains, so that if the track was mined, disabled, or otherwise attacked, they would become the first casualties. Confronting this terrible adversity, some hostages sang as loud as they could to try to alert rebel fighters to their presence and thus perhaps stay alive. ${ }^{83}$

The use of Palestinians as human shields fit the British military's increasingly racialized conception of the Palestine counterinsurgency as a "small war" - parlance for a colonial war. So-called small wars were fought against unconventional or guerilla forces rather than states and against peoples the British deemed uncivilized. They called upon their own tactical playbook of dirty warfare - one which "may shock the humanitarian," as Callwell, the doyen of early twentieth-century British counterinsurgency theory, put it. ${ }^{84}$ In colonial Palestine the military manifested its claim to racial-civilizational supremacy by referring to Arabs with older epithets like "wogs" and "woggery" and calling the rebels "oozlebarts" and other corruptions of the Arabic word isabat (armed bands). Fighting rebels was known as "oozling" - a term that meant hunting down a racial other. ${ }^{85}$ This vocabulary, which appears with particular frequency in documentary sources from 1938 onward, was freely used by commanders as well as rank-and-file, albeit mostly in private communications. ${ }^{86}$ As in other colonial wars, dehumanizing discourse bred a degree of sadism in some of the counterinsurgents in Palestine, thus human shielding could be understood as "a dirty trick," as one soldier put it, "but we enjoyed it." 87

The conscription of Palestinians to act as human shields was a graphic and somatic display of power. It was also utterly shocking to the men so used. Being strapped to the front of a military vehicle or thrust into other transport for hours of harrowing "duty," often in the darkness of night, turned mundane objects and spaces (roadways, railroads, and their conveyances) and everyday activities (translocal movement) into horrific scenes of mortal terror and threat. Human shielding was an object lesson in power for those impressed into the role and for the Arab population alike. Its purpose was not only "practical" (saving British and Jewish lives), but spectacular and symbolic (exhibiting the absence of value accorded to Arab lives). Its means were the very bodies of the Palestinians, requisitioned as battlefield implements against their fellow nationals, to be used and disposed of without a care for protecting the

82 Hughes, "From Law and Order," 15.

83 Segev, One Palestine, 425-26; Naomi Shepherd, Ploughing Sand, 211.

84 Khalili, Time, ch. 1, esp. 27-29. See also Hughes, "From Law and Order," 7.

85 Shepherd, Ploughing Sand, 194; Hughes, "Banality," 332; H. M. Wilson diary, 60, MECA.

86 E.g., Naval reports at BNA, CO 733/366/4; O'Connor to Wetherall, 22 Jan. 1939; and Wetherall to O'Connor, 23 Jan. 1939, LHCMA, O’Connor papers 3-4.

87 Norris, "Repression," 34. 
hostages' essential right to life. As such, human shielding was part of the performative practice of "small wars," where a major objective is "overawing" the population. ${ }^{88}$ Interestingly, despite its intended semiotic effect there is some indication that the rebels understood human shielding completely differently, as a sign of the British regime's "failure, disappointment [khadhlan], weakness, and cowardice," as one missive put it. ${ }^{89}$

The toll taken on the population by human shielding ignited a spate of protests, particularly in the north. The residents of Acre and Haifa called a general strike in September over the tactics of the counterinsurgency, and in the former, human shielding was expressly condemned. The government responded by arresting and interning protestors. ${ }^{90}$ Acre's notables sent a petition to the League of Nations asserting that "The troops ... seem to be unable to patrol the villages without unjustifiably arresting many villagers, and taking them with them during their patrol duty." Their petition describes the use of human shields as a form of torture. In one incident that the military authorities later confirmed, a priest named Anton Zeitun was taken from a village in the Galilee, ostensibly without the troops, who did not speak Arabic, understanding that they had impressed a man of the cloth into being their shield. ${ }^{91}$ Human shielding elicited criticism from some Britons living in Palestine as well. Officials of the Anglican Church in Jerusalem remonstrated against "mine-sweeping," which Bishop George Francis Graham-Brown informed the Archbishop of Canterbury was commonplace in the north. Other British observers referred laconically to human shields on the railways as "suicide' squad[s]." 92

Though officials in Palestine denied it, human shields were also employed in combat. According to the Acre petitioners, this was little different from the situation with the roadways, with captives from the Arab population regularly thrust ahead of British troops during hostilities: "Whenever an engagement takes place, these villagers [the human shields] are placed in the forefront and exposed to danger." ${ }^{.93}$ The most remarkable and visible instance of such conduct came amidst the aforementioned re-conquest of the Old City of Jerusalem in October 1938. Bahjat Abu Gharbiyya, a Jerusalemite youth activist and rebel, describes how the cancellation of the curfew halfway

${ }^{88}$ Khalili, Time, 28-29; last quote citing Callwell.

89 Letter from Acre, 27 Aug. 1938, in Watha'iq al-haraka, 500.

90 Letter from Acre, 17 Aug. 1938, in Watha'iq al-haraka, 496; HMS Malaya, 24 Sept. 1938, BNA, CO 733/366/4; CID, situation report, 20-27 Sept. 1938, MECA, Tegart papers 1-2.

91 'Abdullah al-Jazzar, et al. to Secretary General, League of Nations, 22 Sept. 1938, enclosure to $\mathrm{HC}$ to CSS, 4 Nov. 1938, BNA, CO 733/368/10.

92 Bishop to Archbishop of Canterbury, 23 Nov. 1938; Ferguson (Amman) to Matthew, 5 Nov. 1938, MECA, JEM 61-4.

93 'Abdullah al-Jazzar, et al. to Secretary General, League of Nations, 22 Sept. 1938, enclosure to $\mathrm{HC}$ to CSS, 4 Nov. 1938, BNA, CO 733/368/10. 
through the operation was used by the troops to intersperse themselves among the throngs that emerged onto the streets in neighborhoods that had not yet been recaptured. ${ }^{94}$ Military reports on the city's recapture systematically expunge this detail, as do the reports of the High Commissioner, but the Haganah's official history corroborates the army's reliance on human shields. ${ }^{95}$

Existing records indicate that the military was hopeful that the practice would curb the rebel use of mines and Jerusalem District Commissioner Edward Keith-Roach writes in his memoirs that human shields effectively eliminated sabotage on the railways. ${ }^{96}$ Far from disappearing, however, mines and transit attacks proliferated after human shields had become de rigeur. There were at least thirty-one transit attacks and an unknown number of mine incidents in September and from the end of the month through October no less than forty-three assaults on transportation and thirty-five mines. ${ }^{97}$ Over less than a week in September "well-laid mines in different parts of the country were responsible for twelve casualties to British troops and nine to Jewish police constables." Earlier in the month an ambush near Masmiya on the Gaza-Jaffa road killed seven Jewish supernumerary police and a mine near Beisan blew up three settlers. The worst mine incident in October injured eight or more Jews in the coastal plain. ${ }^{98}$ With casualties piling up, Galilee District Commissioner Alec Kirkbride judged mines the most "trying" form of rebel attack. Sabotage of the railroads also reached new heights, knocking out rail service between Palestine and Egypt for over a week. This followed the announcement by one of the top rebel commanders, Muhammad al-Salih al-Hamad (a.k.a. Abu Khalid), that the insurgents would mine and disrupt the roads and rails in a deliberate campaign to block the arrival and deployment of reinforcements, which often entered the country via Egypt. ${ }^{99}$

In his monthly report for September 1938 the High Commissioner highlighted the "Considerable skill and ingenuity" with which the "infernal machines" were used, noting: "Land mines are common features of the rebel warfare and a source of danger and anxiety to all who have to use the roads and tracks. Road blocks, too, often contain land mines hidden among the

${ }^{94} \mathrm{HC}$ to CSS, 17 Oct. 1938, \#694, BNA, CO 733/366/4; Abu Gharbiyya, Fi khidam, 110-11.

95 HC to CSS, 22 Oct. 1938, BNA, CO 733/366/4; GOC to WSS, 30 Nov. 1938, 6, BNA, WO 32/9498. The Haganah's version of events is cited in Porath, Palestinian Arab, 110-11.

${ }^{96}$ HMS Malaya, 8 Sept. 1938, appendix IV, BNA, CO 733/366/4; Keith-Roach, Pasha, 196.

97 Compiled from CID situation reports, MECA, Tegart papers 1-2; and HC to CSS, 4 Oct. 1938, \#655, 12 Oct. 1938, \#677, 19 Oct. 1938, \#702, 26 Oct. 1938, \#742, and 2 Nov. 1938, \#774, BNA, CO $733 / 366 / 4$.

98 Report to the League of Nations, 1938, 14; Zu'aytir, Yawmiyat, 430; HC to CSS, 9 Oct. 1938, \#671, BNA, CO 733/366/4; CID, situation report, 4-11 Oct. 1938, MECA, Tegart papers 1-2.

${ }_{99}$ DC-Galilee to Chief Secretary, 3 Oct. 1938, 2, BNA, CO 733/372/18; Report to the League of Nations, 1938, 14-15; Note on Leaders of Armed Gangs, n.d., 9, enclosure to HC to Downie (CO), 24 Sept. 1938, BNA, CO 733/370/9. 
stones, which go off when the block is being removed." Such roadblocks could be numerous, with seventy-eight counted one week between Hebron and Jerusalem alone. ${ }^{100}$ Rebel technical proficiency with mines was seen not only in booby-trapping roadblocks, but also in developing new types of mines that might avoid killing their fellow countrymen acting as human shields. One such design used a delayed action trigger, so that the mine was not set off by the first vehicle to cross it, but would, in the event of a typical convoy, explode under a subsequent vehicle. Another employed electric triggers, allowing for controlled remote detonation. ${ }^{101}$

It was only in November, with the doubling of British forces completed and an onslaught rapidly unleashed across the country, that rebel pressure on the transportation network slackened. The search regime was put into overdrive, dragnetting hundreds of communities in the final months of 1938. Moreover, it was combined with new practices of temporary mass incarceration of entire villages and urban quarters that were used to comb through their populations more systematically and thereby (finally) develop actionable intelligence on rebel formations. ${ }^{102}$ To this retooled machinery of repression was added what the military regarded as "the outward and visible sign of Military Control," a pass law system of movement controls imposed from November onward. All movement in motorized vehicles was barred without a permit from the military, and permits could only be acquired by those who obtained identification cards - a new technology of securitization that would be used to track the populace and close in on rebels and their associates. ${ }^{103}$ The rebels effected a short-lived boycott of the new movement control regime, but ultimately the pass law left the public vulnerable to "ruin and starvation" by jeopardizing its food security and threatening its already depressed businesses with commercial failure and bankruptcy. ${ }^{104}$ By 1939 the colonial state's post-Munich counteroffensive had put the rebels on the defensive. ${ }^{105}$

Still, the rebels' ability to attack the transportation network and attempt to impair the state's control of territory and space remained difficult to completely stave off. Transit attacks rebounded from late December through January 1939, with no less than fifty-seven assaults against British or Jewish

100 Narrative dispatch \#10, HC to CSS, 24 Oct. 1938, 57, BNA, CO 935/21; unknown author, 13 Oct. 1938, MECA, JEM 61-4.

${ }_{101}$ HMS Malaya, 8 Sept. 1938, appendix IV, BNA, CO 733/366/4; narrative dispatch \#10, HC to CSS, 24 Oct. 1938, 57, BNA, CO 935/21; Royal Air Force (Jeru.), 20 Oct. 1938, Sept. operations, BNA, Air 5/1248.

102 Anderson, "From Petition," 1055-68.

103 Report on Military Control in Palestine, 1938-1939, April 1939, 29-37, BNA, WO 191/89.

104 Narrative dispatch \#11, HC to CSS, 3 Dec. 1938, 67, 76 (quote); and narrative dispatch \#12, HC to CSS, 29 Dec. 1938, 83, BNA, CO 935/21.

105 Anderson, "From Petition," ch. 10, esp. 1086-93. 
traffic. ${ }^{106}$ The rebels displayed "remarkable pertinacity," as Haining put it, noting in his summary report covering events from November 1938 through March 1939 that "The landmine on roads and railways still continues to be a grave menace to the lives and nerves of all ranks engaged on patrol duties." Official escorts for all Jewish and British traffic remained necessary during the same period. ${ }^{107}$ The overall pace of rebel transit attacks slowed in 1939 under the mounting pressure of the colonial counteroffensive, but their effectiveness and lethality were undiminished. In April four soldiers were killed and two seriously wounded by a mine on the railway near Lydda. In June, with all major rebel commanders killed, captured, or retired from the field, an ambush killed four British personnel and three Jewish supernumerary police. ${ }^{108}$ Months later, on the eve of World War II, hundreds of Arabs joined together to sabotage miles of railway track between Gaza and Rafah, impairing service between Palestine and Egypt for half a year. ${ }^{109}$

\section{BRITAIN'S DEFENSE OF HUMAN SHIELDS}

Unlike many other tactics, such as aerial bombardment, which were approved in London beforehand, the Palestine administration studiously avoided any mention of the use of human shields in its official correspondence. ${ }^{110}$ It is unclear whether military commanders ever informed the Palestine administration about, let alone requested authorization for, the routine use of human shields, and, illustrating either a breach in the chain of command or the wide leeway afforded to regional commanding officers, the practice may have emerged at the brigade level first, before being approved by GOC Haining. ${ }^{111}$ Top local civilian officials appear to have been willing to silently go along with human shielding, and by not reporting it, likely sought to avoid both the embarrassment it entailed and having to candidly disclose the extent of the military's disregard for civilian authority. Yet the protests it set off, followed by the Palestine government's ham-handed manner of trying to dismiss them, belatedly put the matter squarely before officials in London. In

${ }^{106}$ CID situation reports for 27 Dec. 1938-31 Jan. 1939; and CID to IG-police, 26 Jan. 1939, MECA, Tegart papers 1-2.

107 GOC to WSS, 24 Apr. 1939, 6-7, BNA, WO 32/9499.

108 HC to CSS, 10 Apr. 1939, \#405, BNA, CO 733/398/2; GOC to WSS, 30 July 1939, 5, BNA, WO $32 / 9500$.

109 Keith-Roach, Pasha, 205.

110 On bombing population centers see the May and June 1938 discussions in BNA, FO 371/ 21870 .

111 Haining backed the regular use of human shields by November 1938 and ordered them "to be employed whenever possible” by early 1939. GOC to O'Connor, 6 Nov. 1938, LHCMA, O'Connor papers 3-2; O'Connor to Wetherall, 22 Jan. 1939, LHCMA, O'Connor papers 3-4. The fact that human shields were used systematically stands in diametric opposition to claims, such as by Hughes (Britain's Pacification, 313-14), purporting that British abuses were "incidental" and exceptional, rather than regularized. 
an effort to rebut the Acre petition, which the Mandatory was duty-bound to submit to the League of Nations, the High Commissioner admitted in November 1938 that because of "the dastardly practice of laying mines in the public roads and tracks" the security forces "required Arab civilian traffic to precede them along certain roads." Unwittingly stoking further concerns over the counterinsurgency's tactics, he attempted to use as an example what was in actuality a revenge attack carried out by British forces at al-Bassa in the border zone with Lebanon. After four of their colleagues were killed by a landmine near the village in August, local troops forced a bus packed with Arab men to ride over a deadly charge that they themselves had placed, deliberately killing at least ten and injuring ten others. Omitting these circumstances from mention, the High Commissioner depicted the carnage as an instance of British troops being spared from harm by a "mine sweeping" vehicle. ${ }^{112}$

The episode at al-Bassa generated more questions than answers about human shielding. Some officials in the Colonial Office were taken aback by the brazen attitude and ungallant conduct of their colleagues in Palestine. Hinting at the deception that was being perpetrated against the home government by administrators and military commanders on the ground, the Colonial Office's senior legal officer, G. Bushe, asked why, if the story was accurate, a packed bus was thought necessary rather than one person in a vehicle. Others objected more forthrightly to what they saw as the immoral and unwarranted character of employing human shields, particularly from among the civilian population. One such voice, J. S. Bennett, pointed out that the use of human shields blatantly upended Britain's stated rationale for its counterinsurgency: while British officials held that the security forces served to protect the public from the rebels, the reliance on Palestinians as shields meant that in fact it was the Arab public that was protecting Britain's military. Senior officials brushed off such qualms and satisfied themselves with fallacious assurances from the Palestine administration that Arabs employed as human shields on the roads (al-Bassa casualties included) were not civilians but rather rebels and suspected persons ("bad hats"), even though the Palestine government had already admitted that this was not the case. Moreover, the Colonial Secretary took the step of preemptively quashing dissent on the subject of the "minesweeping taxi," effectively instructing his department to toe the line established at Government House in Jerusalem. ${ }^{113}$ Nevertheless, the military in Palestine was subsequently

112 HC to CSS, 4 Nov. 1938, BNA, CO 733/368/10; Hughes, "Banality," 336. MacMichael's monthly report also conceals the fact that the al-Bassa incident was a reprisal: narrative dispatch \#10, HC to CSS, 24 Oct. 1938, 57, 59-60, BNA, CO 935/21.

113 Minutes by Bennett, 10 Dec. 1938, Luke, 16 Dec. 1938, and Downie, 16 Dec. 1938 on HC to CSS, 4 Nov. 1938; Downie to Chief Secretary, 24 Dec. 1938, Chief Secretary to Downie, 23 Jan. 1939, and minutes on last, esp. by Bushe, 7 Feb. 1939, BNA, CO 733/368/10. 
warned by the War Office that "public opinion" was souring on human shields, but the former continued to defiantly insist on their effectiveness. ${ }^{114}$

The fact that the Acre petition was addressed to the League of Nations compelled the London authorities to go on the international record supporting the use of human shields. Customarily, the Mandatory power submitted memoranda alongside the petitions it transmitted to the Secretary General that dismissed the grievances of its colonial charges. Drafting the rebuttal to the Acre complainants caused some consternation at the Foreign Office, which had responsibility for the task, yet ultimately its letter to the League not only repeated the justifications offered for the practice by officials in Jerusalem but amplified them. While the government was aware that the procedure entailed the use of civilians, its official explanation contended deceitfully that only Arabs detained for rebel activities or suspected of the same were employed as shields. Further, it disclaimed all responsibility for the deaths and injuries caused by using human shields, insisting, "If untoward consequences have resulted to such offenders, the blame lies with those guilty of the practice of mine-laying and not with the troops who were patrolling the roads in the interests of public security." Although it mounted a resolute, if whitewashed defense of the practice, the government in London sensed that the issue could bring it great disrepute. It thus attempted to minimize controversy by inaccurately claiming that its employment was extraordinary, rather than standard operating procedure, while insisting, illogically, that it was intended to prevent injury being caused to the public by rebel mines. ${ }^{115}$

British trepidation in defending human shields at the League of Nations certainly owed to the practice's ill-repute as a "method[] which would not be countenanced in ordinary warfare," yet there was little to fear. ${ }^{116}$ Syrian pleas for relief from French repression during the Syrian rebellion in the 1920s were not only rebuffed by the League, but met with an evaluation clearing the French of charges of brutality. ${ }^{117}$ Palestinians subjected to the racial domination-cum-tutelage of the Mandate system fared no better: British records show no substantive response by the League on the human shielding issue and its Permanent Mandates Commission session on Palestine in 1939 was entirely devoid of attention to the counterinsurgency. ${ }^{118}$

\footnotetext{
114 Minute by Burns, 7 Mar. 1939, on Chief Secretary to Downie, 23 Jan. 1939, BNA, CO 733/ 368/10; minute by Baxter, 4 May 1939, on Luke (CO) to Foreign Undersecretary, 13 Apr. 1939, BNA, FO 371/23233.

${ }^{115}$ Luke (CO) to Foreign Undersecretary, 13 Apr. 1939; Baggallay (FO) to Luke, 8 May 1939; and Baggallay to Secretary-General, League of Nations, 26 May 1939, BNA, CO 733/368/10.

116 Minute by Luke, 16 Dec. 1938, on HC to CSS, 4 Nov. 1938, BNA, CO 733/368/10.

117 Provence, Last, 173-74, 176-78, 180.

118 League of Nations, Permanent Mandates Commission, Minutes of Thirty-Sixth Session, June 1939.
} 
HUMAN SHIELDS, THE MILITARIZATION OF THE MANDATE, AND

PALESTINIAN RACIALIZATION

The racialization and dehumanization of the Palestinians during the counterinsurgency in Palestine have often been dismissed or passed over in the scholarship on the Great Revolt. Matthew Hughes has brushed aside the "Casual racism" of British forces and deemed their campaign "humane and restrained" even as he has copiously documented what he memorably refers to as its "banality of brutality." Most recently, his extensive study of the counterinsurgency argues that it was "so effective" because of its "application of measured force" while denying that colonial violence reflected "the underlying racism of empire." 119 While not an apologist for British conduct, Matthew Kelly suggests that race was a factor of declining importance throughout the interwar British Empire, including Palestine. ${ }^{120}$ Even works that foreground the repression and indiscriminate tactics used in suppressing the revolt avoid consideration of race and racialization. ${ }^{121}$ Almost alone among scholars, Laleh Khalili has illustrated a countervailing approach, arguing broadly, "Racialization of the enemy is crucial to liberal counterinsurgencies, in that ultimately a racial hierarchy resolves the tensions between illiberal methods and liberal discourse." Her work further emphasizes that racialization during the Great Revolt was instrumental in collapsing the distinction between civilians and combatants as part of a process in which civilians were not "collateral but ... the central object of war making." 122 The systematic use of human shields opened a new dimension in this process, converting colonized bodies from objects of punishment and surveillance into direct tools of warfare. In doing so, human shielding deepened the racialization of the Arab population. Where the Palestinians had already seen their juridical and individual rights blotted out by the expansive system of collective punishments, human shielding transposed the racial order of the Mandate directly onto Palestinian bodies, somatically manifesting the colonial state's will to protect Britons and Jewish settlers and its stark disregard for Arab life. In the broad scope of Britain's dirty war in Palestine, human shielding was just one of the many ways that the empire rendered the lives of the colonized tenuous and disposable. Yet it marked the absolute withdrawal of basic rights from the colonized.

For the military, the employment of human shields reflected its Hobbesian view of Palestinian society and, as well, the deep current of resistance that had welled up in its ranks against the Mandate's civil administration. Throughout the revolt military leaders pressed for direct control of the counterinsurgency,

\footnotetext{
119 Hughes, "Banality," 352, 354; idem, Britain's Pacification, 157, 160.

120 Kelly, Crime, 73-76, 117.

121 E.g., Shepherd; Segev; Norris, cited herein.

122 Khalili, Time, 4-5; and "Location," 427.
} 
and effectively of the colonial state, on the grounds that civilian officials lacked the necessary spine to scourge the natives. The military's quest for state power was evident not so much in any direct interest in taking over administrative responsibilities, but instead in evading civilian oversight and in dictating the terms of military strategy and tactics, and thus in drawing the contours of the colonial state's relations with the Palestinian majority. From the military's perspective, being assigned to defensive responsibilities such as guarding state assets and personnel represented an undue "restriction" and a misuse of its capabilities. ${ }^{123}$ From the outset in 1936 it rejected the principle of restraint inherent in MACP and the necessity of discriminating between combatants and non-combatants, finding this kind of "forbearance" abhorrent. Consequently, during the second phase of the uprising, military officers took it upon themselves to sidestep the civil power, disregard MACP, and unleash indiscriminate violence as a means of intimidating the Arab public. Some justified this approach by contending that deliberately inflicting greater doses of brutality was actually more humane, and certain commanders, such as Evetts and Bernard Montgomery in the north, cultivated an iron fist approach with little checking them. ${ }^{124}$ As the military struggled and failed to reverse the dramatic gains made by the rebels in 1938 , its tendency to blame civilian officials reemerged and its willingness to resort to ever harsher and blunter tactics grew. From this perspective, the use of Palestinians as human shields not only sent a chilling signal to the colonized. It also stood the priorities of civil government on their head: Where MACP mandated that the military defend the civil regime in order to restore and extend its rule over the colonized, the adoption of human shields eroded the state's relationship with Arab society, spreading alienation and "bitterness" while vitiating colonial claims to be defending the public in the most graphic fashion. The ease with which the military in Palestine brought the home government around to accepting and defending the use of human shields internationally, with all the potential stigma attached, is thus a remarkable indication of its ultimate ascendency within Palestine, irrespective of the formal hierarchy of state authority. It also indicates the very real threat of a rebel victory and the imperial license that was given to dispel it.

The regularization of human shielding served as proof of "the dark path of repression" foreseen and warned against by the Peel Commission. ${ }^{125}$ It was also elemental to an ongoing process of colonial racialization that robbed the Palestinians of their humanity, stripped them of any figment of legal rights

123 Palestine: Discussions, October 1938 - first meeting, 7 Oct. 1938, BNA, FO 371/21864.

124 Hughes, "Terror," 594; Keith-Roach, Pasha, 194.

125 Report of the Palestine Royal Commission [the Peel Commission], Cmd 5479 (London: HMSO, 1937), 373. 
or protections, and denuded them of the most basic security of life. Indeed, with the systematic use of human shields, the colonial regime veered towards the "negation of all law" so feared by top civilian officials and took Palestinian society with it into the ensuing abyss.

\begin{abstract}
This article examines the origins of human shielding - the practice of employing hostages on the battlefield - in Arab Palestine during the Great Revolt in the 1930s. The Palestinian rebellion vexed the British for over three years, and during its second phase (1937-1939), lightly armed rebels beat back the colonial authorities from broad stretches of the country, putting continued colonial control of the territory in serious jeopardy. Britain only defeated the insurgency through a harsh repertoire of collective punishments and "dirty war" tactics. British forces used Palestinians as human shields in a systematic fashion during the revolt's second phase, attempting thereby to stave off the insurgents' consistent and effective attacks on transportation arteries. Beyond its battlefield rationale, this article contends that human shielding was critically tied to two other dynamic processes. The military's adoption of unauthorized tactics like human shielding was part of a broader pattern of rejecting its institutional subordination to civilian authorities and of seeking direct control over the Palestine government in order to assure its unfettered command over the revolt's suppression. At the same time, the conversion of colonized bodies into literal shields bespoke a process of deepening, corporeal racialization that had profound consequences for the Palestinians, stripping them of any figment of legal rights or protections and signaling the utter disposability of Arab life.
\end{abstract}

Key words: Palestine, Palestinian nationalism, anti-colonialism, insurgency, counterinsurgency, British Empire, human shield, peasant, League of Nations, Middle East 